\title{
Cyber PR Technology to Build Brand Awareness
}

\author{
M Solihat ${ }^{*}$, F P Pratami ${ }^{2 *}$ \\ Departemen Ilmu Komunikasi, Universitas Komputer Indonesia, Indonesia \\ Email: ${ }^{1}$ manap.solihat@email.unikom.ac.id
}

\begin{abstract}
The movement of tourism in Indonesia is increasingly showing progress every year, coupled with increasingly rapid technological advances resulting in technological innovations in the tourism sector. Information technology positively influences tourism sector, such as online ticket booking applications, especially during COVID-19 pandemics. This study aims to determine how online ticketing applications affect tourism and their impacts during a pandemic. One of them is about the influence of ticket and hotel booking application technology in the tourism sector, affecting tourists' behavior in traveling, and the condition of tourism today. This study method was distributing questionnaires to respondents. The analysis used statistics to determine the effect of online ticket booking applications on tourists' increase in Indonesia. This study indicates that this application makes it easy for tourists to travel, such as a hotel booking feature and purchasing tickets for tourist destinations online and increasing tourists' number. The majority of respondents stated that online applications help manage their trips during the pandemic.
\end{abstract}

Keywords: Cyber, Public Relations, Brand Awareness, advertisement

\section{Introduction}

The role of Public Relations (PR) has become a necessity for many companies to compete in the current era of globalization. Of course, this cannot be denied because public relations have the main function of forming and maintaining a positive image of the company or organization [1]. Entering the era of new media, such as now, public relations are required to act dynamically following developments in technology and information, especially the internet; since then, in the field of public relations, the term Cyber Public Relations has emerged. Public relations are carried out to build and maintain an image, brand, and trust to the public, which is interactive via the internet [2]. One of the Cyber PR activities to promote a brand is to build brand awareness. Keller in Rahayu revealed that brand awareness is the ability of consumers to recognize and remember a brand by only seeing certain logos or slogans used in promoting the products or programs it runs [3].

Quoting from eMarketer, globally, social media users in 2022 are estimated to increase to 3.29 billion, and it happens to be $42.3 \%$ of the world's population [4]. Meanwhile, in Choi and Greene'e's study, in recent years, the growth in social media use by individuals to communicate and share content with other users has generated opportunities and challenges 


\section{International Journal of Research and Applied Technology}

1(1)(2021) 76-83

Journal homepage: https://ojs.unikom.ac.id/index.php/injuratechInternational

for firms, offering a new tool to interact with current and potential customers [5]. Ahmad et al., in their study, revealed if communicating the brand on social media plays an essential role in communicating the brand effectively to customers so that they can continue to connect with the brand [6]. The magnitude of the strength of communication made by a brand with customers will also have high customer loyalty. The most important thing is that the strong relationship built can lead consumers to their choice and loyalty to the brand [5]. Cyber PR technology's contribution in building brand awareness cannot be separated from negative impacts. Placing the wrong brand strategy may cause a bad image in the company's reputation itself, and there is a possibility put the company in a bad situation such as: viral in social media, which does significant damage or suffer huge losses [7]. Therefore, to avoid unexpected mistakes, companies should continuously improve cyber PR technology to build brand awareness to maintain customer loyalty to the brand [8].

From previous research that discussed cyber PR technology to build brand awareness, it is explained that in the era of new media, such as today, public relations must be able to act dynamically to keep up with developments of technology and information. It has also been explained that cyber PR technology through social media to build brand awareness can have a positive impact, create a loyal customer to the brand, and make customers select the brand as the product that they believe. Cyber PR technology to build brand awareness will still be met with negative impacts, if you put the wrong brand strategy, it can damage the company's reputation, and there is the possibility to go viral to lead the company to suffer significant losses. However, in this qualitative descriptive study, students aim at seeing how effective cyber PR technology is to build brand awareness in today's times. Students also survey to find out.

\section{Method}

This research is a descriptive study that used a questionnaire survey method. Researchers collected some information from 32 respondents that shared it through social media or online from this survey. Meanwhile, the survey collects all data from society or population through questions given by researchers to respondents individually. We obtained respondents who answered our question through this questionnaire, the average UNIKOM student, students from other universities, and fresh graduate workers whose residence is in Bandung, West Java.

\section{Results and Discussion}

The following is data obtained from questionnaires for our research titled Cyber PR Technology to Build Brand Awareness:

\subsection{The effectiveness of Cyber PR to Building Brand Awareness In The New Media Era}

It is shown in Figure 1 that the effectiveness of Cyber PR in new media such as per-now is beneficial to build brand awareness because, in the internet media, there are many advantages that companies can do to attract customers. Companies must follow modern trends to make sure that the products they produce are sold and not outdated. According to Isabel Buil et al., in their research, they use internet media in their daily activities. It is advantageous for companies to promote their brand and increase brand awareness through social media platforms. With Brand Awareness, we can find out how well-known our brand in the consumers' view. The company needs to attract consumers and build brand awareness to choose our brand. Therefore, we need to promote the company's brand creatively and 

grows when consumers recognize the company's brand $[9,10]$. The following is data obtained from a questionnaire for our research titled Cyber PR Technology to Build Brand Awareness (Figure 1):

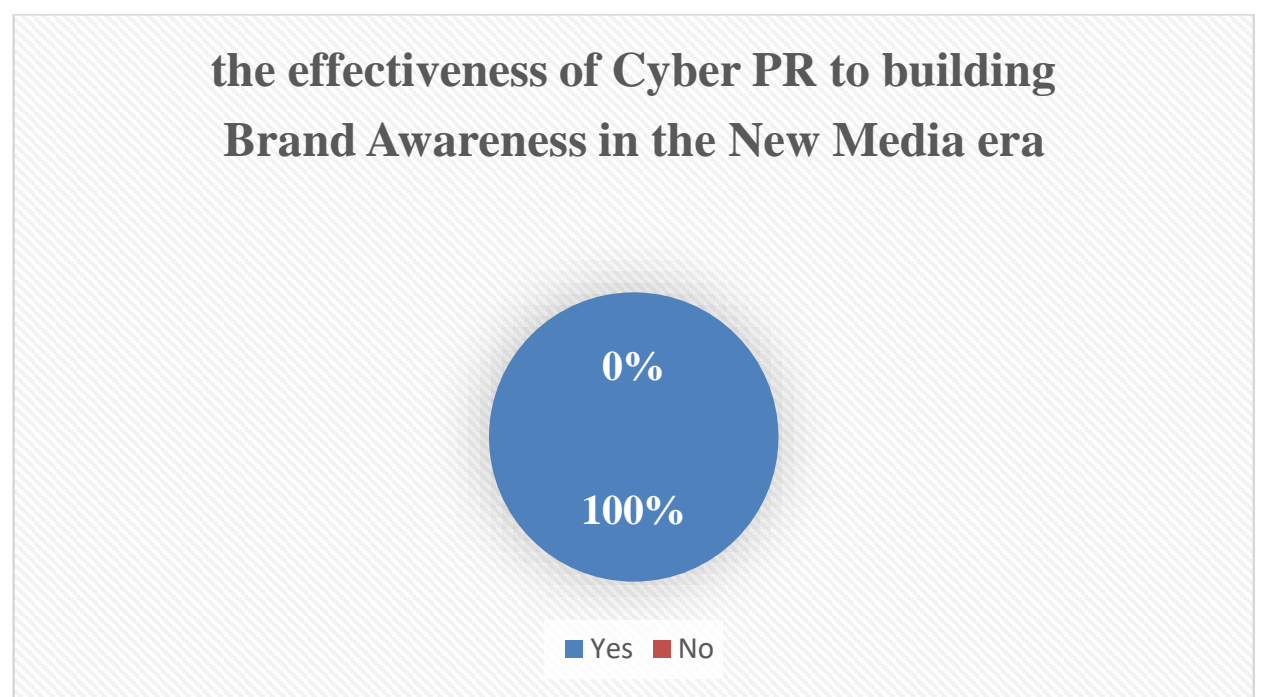

Figure 1. The effectiveness of Cyber PR to building Brand Awareness in the New Media era

In the first question survey, of the 32 respondents selected were:

- $100 \%$ of respondents voted yes that Cyber PR technology in the new media era was effective to build brand awareness from an average of 27 women and 5 men

Internet media technology that is mentioned by Cyber PR technology is such as Instagram, Facebook, Youtube, and other internet media. The development of internet media technology has been very fast and widespread and made us realize that in the modern era like now, we can do unlimited interaction and can also do business, social, and economic networks through the internet. With internet technology, many companies are utilizing internet media as a means of publication and communication to support the effectiveness of the company's operations so that consumers can select their products.

Brand awareness is one of the important components of brand equity. The first step to build brand equity is to create brand awareness. According to Tong and Hawley, brand awareness is a source of brand equity. Brand awareness results in brand equity in four different ways: creating a brand node in consumer's memory, providing a sense of familiarity of the brand in the consumer's mind, acting as a signal of trust in the brand, and being enough reason for the consumer to consider the brand in his consideration set. One of the advantages of communication in social media is the ability to reach consumers because they are searching for information and expand brand awareness, helping to create favorable associations, which create a brand image [4].

\subsection{The Influence of Advertising on Purchasing Decisions for Consumers}

It is shown in Figure 2 that the advertisement is affects consumers' decisions when purchasing goods. According to Chioveanu research, an advertisement could influence the 


\section{International Journal of Research and Applied Technology}

$1(1)(2021) 76-83$

Journal homepage: https://ojs.unikom.ac.id/index.php/injuratechInternational

decision to buy a brand that the consumer will choose; if the consumer has already chosen the brand could lead to loyalty as a customer. Keller describes advertising as a type of communication for marketing that induces various effects on brand equity. Besides, Eng and Keh, in their research, said that invitation in advertising was important for brand equity. It is also to influence consumers to choose the product. The brand's confidence can be equated with consumer confidence that consumers' brand will provide the expected equity value [9]. It means brand equity is the value of the brand carried by the company. For example, when we think of boba drinks, the first brand that you think of is the one that already has brand equity. In the second question survey, of the 34 respondents selected were (Figure 2):

\section{The Influence Of Advertising On Purchasing Decisions For Consumers}

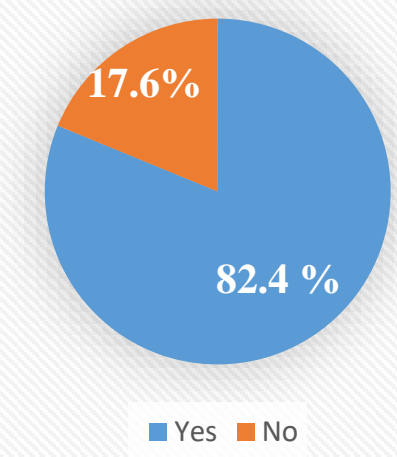

Figure 2. The Influence of Advertising on Purchasing Decisions for Consumers

- Around (82.4\%) or 28 respondents voted yes, that the influence of advertisements served or shown on the internet influenced a consumer's decision to buy products from the brand.

- Moreover, about (17 $6 \%$ ) or 6 respondents chose not to, that the influence of advertisements served or shown on the internet did not affect a consumer's decision to buy products from the brand.

- In this new media era, companies must know how to utilize and manage internet media to build a positive image and build Brand Awareness. With companies using internet media, consumers can see or choose our products appropriately [4].

- The following chart will explain whether Brand Ambassador can affect consumers.

\subsection{Brand Ambassador Influences Consumer to Choose Product}

It is shown in Figure 3 that the Brand Ambassador it could influence consumers to buy products. According to Anderson and Ekman, using brand ambassadors is more effective and more cost-effective than using advertising. Brand ambassadors can also distinguish consumers' attractiveness and be an opinion leader who gives new ideas according to the public figure's image. Quoted from Rogers and Cartano, brand ambassadors are usually people who can influence the community so that consumers can select the products they offer. 
Usually, this Brand Ambassador is used as a representative of the company and becomes the company's face or icon [11] (Figure 3).

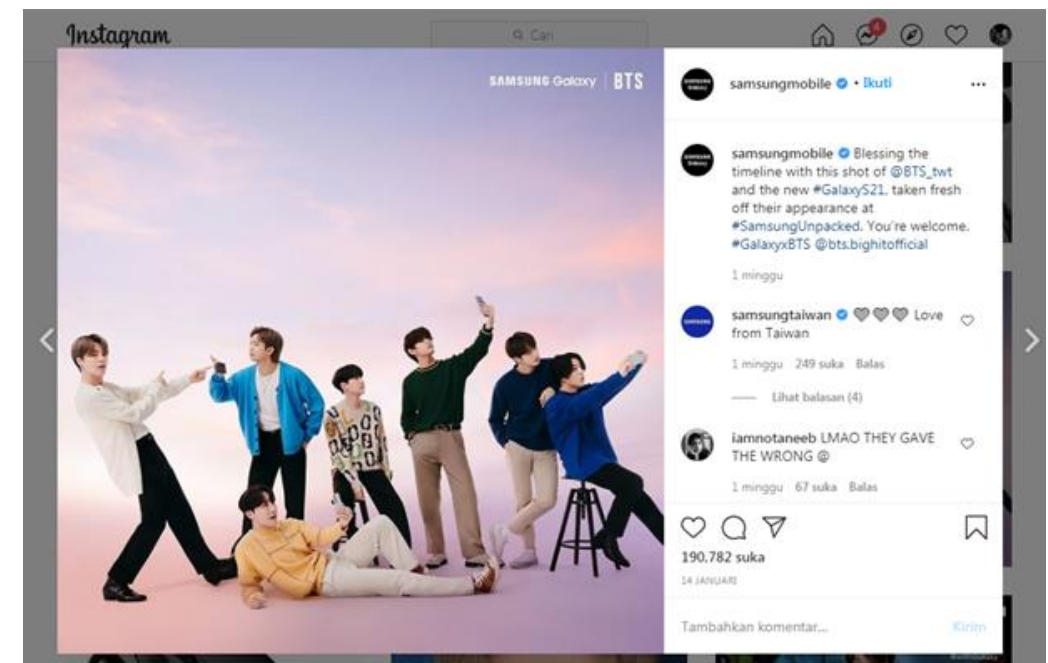

Figure 3. Examples that the Brand Ambassador influences consumers to choose the product.

We take Samsung products, for example. On the internet media, namely Instagram, Samsung posted a photo of BTS. It is well known that currently, BTS's popularity is rising; Samsung took advantage of the opportunity by choosing BTS as their product Brand Ambassador. As a result, sales of Samsung's S20 series mobile phones ranked first in March 2020. It proves that Brand Ambassador is influencing consumers to choose products.

In this survey, the Brand Ambassador influences you to buy or choose products (Figure 4).

\section{Brand Ambassador Influences Consumer To Choose Product}

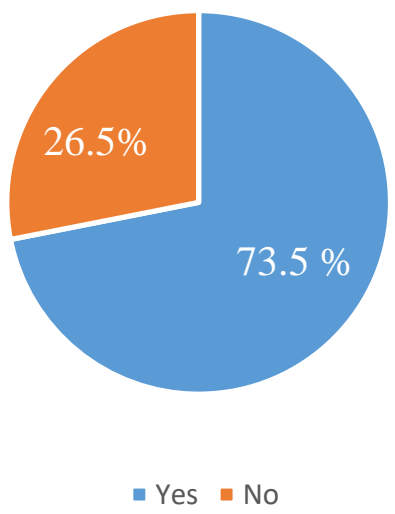

Figure 4. Brand Ambassador influences you to buy or choose products 
- Around $73.5 \%$ or 25 people voted yes that the Ambassador brand affected consumers to buy products.

- Approximately $26.5 \%$ or 9 people voted no, that brand ambassadors do not influence consumers to purchase products.

\subsection{Effective Technology for Cyber PR}

It is shown in Figure 4 that Cyber PR technology in the era of new media such as public relations must follow the development of technology, and the internet is growing rapidly, especially internet media. As Cyber PR, we must do some activities to build brand, image, and trust to the public through internet media to continue to choose our products [2]. From the various internet media above, the survey also chooses that all internet media advertisements can raise products in a company or brand. According to Mangould and Faulds, the development of internet media is widely used by companies to change their product marketing. Meanwhile, Gallaugher Ransbotham's, Tsimonis's, and Dimitradis's study presented that companies use internet media to interact with consumers or customers, attract new customers, and share the latest information about their products and build the brand. The presence of social media for the company is to build and improve products so that the company can open information, needs, and opinions of wider customers, thus other companies are also increasingly interested in using internet media and more responding to information from customers to produce better products [5]. Internet media provides some advantages to the company to communicate in two directions to shareholders. Another advantage is that internet media could inform us whether consumers like or dislike the product or brand. However, internet media also has negative aspects, such as when someone comments negatively on the brand can automatically decrease loyalty to the company. Many of the company's internet media was hacked [8]. In this survey, the most effective technology for Cyber PR is as follow (Figure 5):

\section{Effective Technology For Cyber PR}

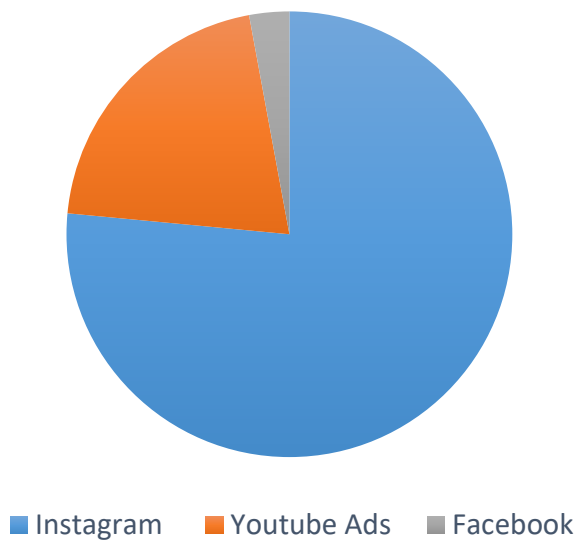

Figure 5. Effective technology for Cyber 4 


\section{International Journal of Research and Applied Technology}

$1(1)(2021) 76-83$

Journal homepage: https://ojs.unikom.ac.id/index.php/injuratechInternational

- Around $76.5 \%$ or 26 people choose Instagram as an effective Internet Media Technology to build Brand awareness.

- Around $20.6 \%$ or 7 people choose Youtube Ads as an effective Internet Media Technology to build Brand awareness.

- About $2.9 \%$ or 1 people choose Facebook as an effective Internet Media Technology to build brand awareness.

It is shown in Figure 4 that Cyber PR technology in the era of new media such as public relations must follow the development of technology, and the internet is growing rapidly, especially internet media. As Cyber PR, we must do some activities to build brand, image, and trust to the public through internet media to continue to choose our products [2]. From the various internet media above, the survey also chooses that all internet media advertisements can raise products in a company or brand. According to Mangould and Faulds, the development of internet media is widely used by companies to change their product marketing. Meanwhile, Gallaugher Ransbotham's, Tsimonis's, and Dimitradis's study show that companies use internet media to interact with consumers or customers, attract new customers, share the latest information their products, and build the brand. The presence of social media for the company is to build and improve products to open information, needs, and opinions of wider customers. Thus, other companies are also increasingly interested in using internet media and responding to information from customers to produce better products [5]. Internet media provides some advantages to the company to communicate in two directions to shareholders. Another advantage is that internet media could inform us whether consumers like or dislike the product or brand. However, internet media also has negative aspects, such as when someone comments negatively on the brand can automatically decrease loyalty to the company. Many of the company's internet media was hacked [8].

\section{Conclusion}

Internet media technology is very useful for companies to build Brand Awareness so that consumers or customers remain loyal to the brand. Cyber PR's job is to provide those creative ideas so that the brand is not outdated and still chosen $\neg$ by consumers. Companies can use advertising on internet media to attract new consumers, and companies can also choose the famous Brand Ambassador to attract a wider market to make the brand more famous. From internet media, companies can also interact with customers to produce better products. Interacting with consumers will build their loyalty to the brand. 


\section{References}

[1] Darwadi, M. S. 2019. Pembentukan Citra Positif Perusahaan Melalui Cyber Public Relations. E-Jurnal Ekonomi dan Bisnis Universitas Udayana, pp.901-915.

[2] Anggraini, C. A., Perbawasari, S., \& Budiana, H. R. 2018. Cyberbranding Sebagai Upaya Membangun Brand Awareness Shopee Indonesia. Commed: Jurnal Komunikasi dan Media, 2(2), pp.72-86.

[3] Susilo, A. 2020. Aktivitas Cyber Public Relations Pada Agen Perjalanan Online Dalam Meningkatkan Brand Awareness. Jurnal Spektrum Komunikasi, 8(1), pp.22-29.

[4] Appel, G., Grewal, L., Hadi, R., \& Stephen, A. T. 2020. The future of social media in marketing. Journal of the Academy of Marketing Science, 48(1), pp.79-95.

[5] Chierici, R., Del Bosco, B., Mazzucchelli, A., \& Chiacchierini, C. 2019. Enhacing Brand Awareness, Reputation and Loyalty: The Role of Social Media. International Journal of Business and Management, 14(1), pp.216-224.

[6] Bilgin, Y. 2018. The effect of social media marketing activities on brand awareness, brand image and brand loyalty. Business \& Management Studies: An International Journal, 6(1), pp.128-148.

[7] Siddiqui, S., \& Singh, T. 2016. Social media its impact with positive and negative aspects. International Journal of Computer Applications Technology and Research, 5(2), pp.7175.

[8] Omar, M. W. O. M. W., \& Ali, M. N. M. 2010. Brand loyalty and relationship marketing in Islamic banking system. Canadian Social Science, 6(1), pp.25-32.

[9] Bakator, M., Borić, S., \& Paunović, M. (2017). Influence of advertising on consumer-based brand loyalty. Journal of Engineering Management and Competitiveness (JEMC), 7(2), 75-83.

[10] Seturi, M. 2017. Brand awareness and success in the market. Journal of International Scientific Publications, 11.

[11] Sadrabadi N, A., Sadraji K, M., Moshizadeh, M 2018. Evaluating The Role of Brand Ambassador In sosial Media. Journal Of Marketing Management and Consumer Behaviour. 